МРНТИ 21.31.35

\author{
Нуржанов Б.Г. \\ Казахский национальный университет имени аль-Фараби, \\ Республика Казахстан, г. Алматы \\ *E-mail: relkaz@gmail.com
}

\title{
ПОСТМОАЕРНИСТСКАЯ РЕАИГИЯ
}

В данной статье рассматривается проблема соотношения и взаимосвязи постмодернизма и религии, особенности постмодернистской религии. Религия на протяжении тысячелетий скрепляла собой общество, объединяла ^юдей, делала их жизнь осмысленной, вдыхала смысл и анимировала все человеческие отношения. Что же происходит с ней в условиях постмодерна? Остается ми она бастионом сопротивления разлагающему влиянию постмодернизма? Обречена она исчезнуть или только метаморфизировать при переходе общества к своей постмодернистской стадии? Автор пытается проанализировать состояние и решение вопроса в модернизме и постмодернизме, их размичие.

Кмючевые слова: религия, Бог, модерн, постмодерн, постмодернизм.

\section{Нуржанов Б.Г. \\ Постмодеристік дін}

Мақалада автор постмодернизм мен діннің арақатынасы мен өзара байланысын, постмодернистік діннің ерекшеліктерін қарастырады. Аін мыңжылдар аралығында адамдарды байланыстырып, қоғамның біріктіруші негізі болды, олардың өміріне мән-мағына беріп, барлық адамилық қатынастарды қалпына келтіріп отырды. Постмодерн жағдайында оған не болды? О^ постмодернизмнің кері әсеріне қарсы тұра ала ма? Оның жоғалып, құрып кетуі мүмкін бе, жоқ, әлде қоғамның постмодернистік деңгейіне өтуіне байланысты ол да бейімделе ме? Автор модернизм мен постмодернизм жағдайында осы мәселенің ахуалын және шешу мүмкіндіктерін айқындауға тырысады.

Түйін сөздер: дін, Құдай, модерн, постмодерн, постмодернизм.

\section{Nurzhanov B.G. Postmodern religion}

In this article, the author examines the problem of the correlation and interrelationship between postmodernism and religion, the features of postmodern religion. Religion for thousands of years fastened the society, united people, made their life meaningful, inhaled the meaning and animated all human relations. What happens to it in postmodern conditions? Does it remain a bastion of resistance to the corrupting influence of postmodernism? It is doomed to disappear or just to metamorphize when society moves to its postmodern stage? The author tries to analyze the state and solution of the issue in modernism and postmodernism, their difference.

Key words: religion, God, modern, postmodern, postmodernism.

На первый взгляд, трудно найти более диссонирующую тему, чем постмодернизм и религия. Многим кажется, что из всех областей культуры религия является наиболее «антипостмодернистской» ее сферой. Именно религия отстаивает все те ценности, против которых выступает постмодернизм, такие как: универсализм (общезначимость) человеческих ценностей, их непреложность во всех исторических трансформациях, эссенциализм, фундаментализм веры (канон), 
более или менее ясный смысл жизни (служение Богу), монистическая онтология (не всегда совпадающую с философской), теория субъекта как основы религиозного опыта и т.д. Со своей стороны, постмодернизму трудно найти более очевидный образец «большого нарратива», чем религия, и тем самым более подходящий объект для критики. Но, замечает Кевин Харт, «Если зайдете в хороший книжный магазин в большом городе и взглянете на полки с книгами по религиозной тематике, то найдете обширную подборку книг, в заголовках или подзаголовках которых присутствуют выражения типа «постмодернистская религия», «постмодернистское христианство», «постмодернистский Бог», «постмодернистская теология» [1].

Вместе с тем, религию нельзя отнести просто к «задворкам культуры», к второстепенным ее институтам. На протяжении тысячелетий она скрепляла собой общество, объединяла людей, делала их жизнь осмысленной, вдыхала смысл и анимировала все человеческие отношения. Что же происходит с ней в условиях постмодерна? Остается ли она бастионом сопротивления разлагающему влиянию постмодернизма? Обречена она исчезнуть или только метаморфизировать при переходе общества к своей постмодернистской стадии? Этот конфликт религии и постмодернизма может быть представлен как поистине вселенский, если учесть, что религия имеет многотысячелетнюю историю и значение, тогда как постмодернизм насчитывает едва ли полсотни лет. Но если мир стал «постсовременным», если постмодернизм радикально изменил все социальные и культурные институты, человеческие отношения, создал новый социально-экономический мировой порядок, то может ли религия оставаться той же прочной основой социальной связи, каковой она была в модерне, до-модерне, архаике? Не обречена ли она исчезнуть как изживший себя институт, как предрекали ей просвещенческая и марксистская философии? Или она имеет возможность смотреть свысока на «суету сует», каковых в ее многовековой истории было легион, и одним из последних в ней является постмодерн? Все пройдет, пройдет и это? А возможно, она имеет способность приспособиться и к постмодернизму, как она неоднократно приспосабливалась ко многим другим историческим изменениям? Все эти вопросы, порожденные постмодернистской трансформацией, заставляют нас вновь поставить вопрос: а что же такое религия?

Но рассмотрим вначале вопрос об отношении постмодернизма к религии. Является ли постмодернизм «окончательным ниспровергателем религии» как последнего большого нарратива, как полагают многие? Или, напротив, религия остается одним из немногих институтов, который показывает тщету и нищету постмодернизма, как полагают еще больше людей? Для прояснения этих вопросов начнем с отношения модернизма к религии. При всей полиморфности и протееобразности модернизма его отношение к религии является удивительно одинаковым: в мягком варианте: религия - устаревший институт, и чем быстрее мы оставим его в прошлом, тем лучше; в более жестком варианте: религия это оковы и цепи на здоровом теле модерна, и ее надо не просто забыть или отбросить, а искоренять огнем и мечом. Все то, что составляет новые ценности модерна - прогресс, новации, индивидуальное творчество, устремленность в будущее, контроль над, и управление обществом, индивидуализм и прагматизм, прямо или косвенно противоречит религиозным ценностям. Именно модернизм провозглашает смерть Бога. Является эта знаменитая мысль Ницше модернистской или постмодернистской?

Но поставим вопрос: является ли отношение постмодернизма к религии таким же, как в модернизме или близким по духу? Постмодернизм в определенном смысле является реакцией на модернизм, точнее, на его институциализацию в культуре капиталистического истеблишмента. Но такое понимание постмодернизма, при всей его справедливости, является зауженным и неадекватным. Постмодернизм - нечто большее, чем просто реакция на... И если постмодернизм дистанцирует себя от модернизма или выступает с критикой его ограниченности, то мы вправе ожидать от него и иной оценки религии, чем модернистская. Поэтому артикуляции типа «постмодернистская религия» или «постмодернистский Бог», о которой пишет Харт, является не просто «постмодернистской склонностью к эпатажу», а явлением, к которому можно подойти со всем подобающим пиететом.

Кевин Харт представляет нам целую плеяду «постмодернистских теологов» и мыслителей, исследующих трансформации религиозности в том, что мы сегодня называем постмодернистской культурой. Это Мишель де Серто, Джон Капуто, Жан-Люк Марион, Джон Милбэнк, Ханс Урс фон Балтазар, Мерольд Уэстфал, Марк Тэйлор, Грэм Уорд, сам Кевин Харт. И мы с удивлением обнаруживаем в этом списке даже Жака Деррида, Мартина Хайдеггера, а также Мориса 
Бланшо, Эммануэля Левинаса, Юлию Кристеву, Люс Иригарэ и др. вполне «респектабельных» постмодернистов. Один перечень имен заставляет задуматься над проблемой соотношения постмодернизма и религии. Харт открывает нам совершенно новый слой постмодернистской культуры, или, по крайней мере, постмодернистской теории, которого редко кто касался из постмодернистских критиков. В этой культуре совершенно иначе, чем в «секулярном постмодернизме», рассматриваются условия его становления, его истоки и история.

Харт предлагает нам «отличать религию, практикуемую в эпоху постмодерна, от религии постмодернизма», - весьма плодотворное различение. Религия в эпоху постмодернизма, безусловно, продолжает существовать, и даже испытывать подъем, при этом чаще всего ни слова не зная ни о постмодернизме, ни о постмодернистах и их работах, ни о глобальных трансформациях культуры. Она оставляет за собой традиционную задачу укрепления своей веры и ее максимальное распространение. Но даже эта традиционная религия испытывает на себе «дыхание времени»: сторонников традиционных конфессий становится все меньше (это, пожалуй, не относится только к исламу, хотя и здесь идет скрытая борьба различных мазхабов и все громче раздаются голоса с призывом модернизировать его), вера из глубокого экзистенциального чувства для многих превращается в пустую формальность и ритуальность, происходит невиданное ранее смешение самых разных религиозных идей, возникновение бесчисленных новых синкретических религий, уже не столько думающих о Боге, сколько о наживе или борющихся за политическую власть. Пестрая смесь восточных и экзотических религий типа дзэн-буддизма, зороастризма, суфизма, вуду вербует своих сторонников среди интеллектуальной элиты.

Отдельной глобальной темой сегодня выступает фундаментализм, в особенности исламский, связанный прямо или косвенно с международным терроризмом, что дало повод Сэмуэлю Хантингтону говорить о «столкновении цивилизаций». В чем лежит причина столь резкого и непримиримого разделения уже не только религий, но и цивилизаций на основе религиозного фундаментализма? Только ли в том, что ислам, как полагают некоторые религиоведы, не прошел стадии модернизации и просвещения? Столь ли невинен сам Запад в этом противостоянии цивилизаций? Почему западные модернистские ценности представляются религии ислама столь чуждыми и нечеловеческими, что подвигают его приверженцев на джихад и массовое (само) убийство? Кевин Харт пишет: «Ради более безопасного мира кандидатам в депутаты сената и конгресса - не говоря уже о соискателях места в Овальном кабинете - следовало бы не столько иметь юридическую и экономическую подготовку, сколько прослушать хороший курс теологии» [2]. Фундаментализм можно понять и как реакцию на постмодернизм, на все более шаткий, неопределенный, утративший смысл мир постмодернизма.

Чем же отличается постмодернистская религия от религии в эпоху постмодерна? Во-первых, приходится признать, что постмодернистская религия - это по-преимуществу постмодернистское христианство, поскольку ни в исламе, ни в других мировых или восточных религиях такого сочетания мы не находим. Или иудео-христианство. В этом плане постмодернистские христиане стремятся осмыслить религию в тесной связи с, и опираясь на художественный и философский постмодернизм, хотя далеко не всегда относят себя к нему. Здесь постмодернизм часто рассматривается как защитник и соратник религиозности в его противостоянии модернизму и модернистскому воинствующему атеизму. Многие исследователи постмодернизма обнаруживают множество точек его родства с до-модерном и традиционалистской культурой. Эти точки родства и разрабатывают постмодернистские теологи. Поэтому постмодернистскую религию часто называют постсекулярной: это не возвращение к традиционной религиозности средних веков или раннего христианства, а позиция, которая признает фундаментальность института религии в культуре и стремится исследовать условия этой фундаментальности. Постмодернистский теолог может быть лично неверующим, как, например, Деррида, что он всегда признавал. Выступая резко против онтологии индивидуализма и социального атомизма, созданной идеологией Просвещения, постмодернистское христианство предлагает нам онтологию участия, активной солидарности, и тем самым «взвалить на себя нелегкую ношу культуры», как пишет Харт.

Постмодернистская религия активно использует деконструктивный метод Деррида и его концепцию различия-откладывания (differance). Она ближе средневековой апофатической теологии, чем катафатической. Последняя пыталась постичь Бога с помощью рациональных процедур, разработанных греческой философией; первая считает невозможным постижение Бога 
с помощью человеческого языка и философии. Деррида и Харт упрекают катафатическую христианскую ортодоксию в подчинении теологии метафизике, тогда как пафос апофатической представляет собой не до конца реализованную попытку создания неметафизической теологии, т.е. попытку вывести идею Бога из-под доминанты бытия. К тому же, фактически, стремился и Хайдеггер в своей идее Бытия, отличного от сущего, превознося Фому Аквинского, утверждавшего превосходство Бога над бытием (бытие Фомы это «сущее» (dasSeiende), в терминологии Хайдеггера, а Бог - подлинное Бытие (dasSein)). Деконструкция метафизической теологии - это исследование вопроса, когда, как и почему Бог стал пониматься в категории бытия, когда, как и почему бытие становится универсальной разменной монетой философии и культуры и подменяет собой Бога.

Применение концепции difference к христианской теологии позволяет постмодернистским теологам лучше прояснить такие фундаментальные символы веры христианства и его таинства, как Троица, богочеловечность или вочеловечение Иисуса, непорочное зачатие и др. Напомним, difference- это дерридианский неологизм, призванный у него подчеркнуть одновременно два важных смысла постмодернистской культуры - фундаментальность различия и непреложность откладывания. Первое подразумевает приоритетность различия перед тождеством (тотальностью, универсальностью) как фундамента культуры, второе - не прямое непосредственное и полное, а всегда «отложенное» присутствие многих важных для культуры вещей, в данном случае Бога. Троица для постмодернистов представляет собой наглядную демонстрацию различия в Боге, его не тождественную (единую), а «различную» природу. Известно, что символ Троицы в христианстве всегда был одним из труднообъяснимых положений догмы, не поддающемуся рациональному объяснению, и потому таинством; вместе с тем, это, пожалуй, центральный для христианства символ веры. Бог изначально и фундаментально различен в Отце, сыне и Святом Духе. Difference как откладывание применительно к концепции Бога помогает понять не прямое и непосредственное, а отсутствующее Его бытие (присутствие): он никогда не присутствует (есть) непосредственно, лично, здесь и теперь, его бытие отличается от бытия сотворенных им вещей и существ, это не бытие, а какой-то иной способ существования, загадочный для метафизики и здравого смысла. То же можно сказать и о концепции богочеловечности Иисуса: он различен в своей сути - одновременно и Бог, и человек.

Если одним из главных вопросов модернистской теологии был вопрос о соотношении веры и разума, теологии и философии, чувства Бога и его понимании, то одним из главных вопросов постмодернистской становится вопрос о соотношении религии и этики. Редко кто в модернистской теологии (Тертуллиан, Августин, Экхарт являются такими исключениями, поэтому их иногда относят к постмодернистам или их предшественникам) отдавал предпочтение вере перед разумом, но никто из них не ставил под сомнение очевидность связи религии и этики. Их единство было «естественным», самим собой разумеющимся и аксиоматическим. Если отбросить ритуальность, исступления, медитативные практики и другие «иррациональные» ее проявления как «внешние элементы» религии, то этика, отношение человека к человеку, скрывающееся за отношением человека к Богу, становится «основой религии» - вот до чего поднимается модернистская мысль. Постмодернистская теология считает естественность этой связи сомнительной, «сфабрикованной» и требующей объяснения. С ее точки зрения религия становится этикой с момента ее рационализации, подчинения веры принципам разума. В первоначальном христианстве равнозначно присутствовали обе тенденции - понимание религии как веры без всякого разума, и как подчиненной необходимости рационального обоснования.

Отсюда открываются совершенно иные горизонты и перспективы возникновения модернизма, чем в секулярном постмодернизме. Недостатком секулярного постмодернизма постмодернистские теологи считают игнорирование важной религиозной составляющей культуры. Модернизм задолго до искусства, и даже науки и философии (Бэкона и Декарта), по их мнению, начинается с Дунса Скотта, и даже с мусульманских философов, как Ибн Рушда и Ибн Сины. Ганс Урс фон Балтазар, например, утверждает, что первыми модернистскими мыслителями являются не Декарт и Галилей, а Аверроэс (XIII в.) и даже Авиценна (XI в.): «Переведенные на латынь спустя столетие после его (Аверроэса-Б.Н.) смерти, эти комментарии оказали сильнейшее влияние на некоторых философов-схоластов, что вызвало тревогу у таких убежденных ортодоксов, как св. Альберт Великий (ок. 1193-1280) и св. Фома Аквинский (ок. 1226-1274). Особенно беспокоило их утверждение примата разума над 
верой, философии - над теологией. В конечном счете для аверроистов богооткровенные истины уступали по статусу истинам разума»[3].

Но подлинным основоположником модернизма в христианской теологии, утверждает Балтазар, и вслед за ним Харт, является Дунс Скотт. Как разделяющий взгляды Аверроэса Дунс Скотт первым утверждает примат бытия над Богом: абсолютом становится уже не Бог, а Бытие, Бог также подчинен бытию (существует), как и продукты его творения - мысль, совершенно еретическая для предшествующей христианской теологии. Но Дунс Скотт отнюдь не был еретиком, отрицавшим (бы) различие Бога и тварных существ. Но способом доказательства бытия Бога для него является уже не Его «небытийность», верховенство перед бытием, а универсальность бытия, в рамках которого мы только и можем доказать существование Бога. «Как бы то ни было, воззрения Дунса-Скотта - а вернее сказать, некоторое их недопонимание, - стали, по мнению Балтазара, точкой зарождения эпохи модерна. Вольно или невольно Дунс-Скотт подтолкнул многих философов к трактовке конечного бытия как собственно бытия, к игнорированию бесконечного бытия, а конкретно - Бога. По сути, концепция бытия Дунса-Скотта тихо-мирно оказалась вознесенной над Богом. Бытие уже не осознается как реальность, а воспринимается как кониепиия. Предполагается, что сам Господь оказался перед лицом концепции универсального, нейтрального и неопределенного бытия» (Харт, 2006, 202).[4].

Именно эта идея универсального и неопределенного бытия Дунса Скотта, а не гуманистические и артистические идеи Ренессанса, по мнению Балтазара, оказала решающее влияние на формирование модернизма. Далее эта идея «была переосмыслена, переориентирована и глубоко развита иезуитским теологом Франсиско Суаресом в его DisputationesMetaphysicae (1597), энциклопедическом труде, опираясь на который большинство европейских философов XVII в. постигали свое ремесло»[5]. До Суареса и Дунса Скотта идея бытия обосновывалась подобием Богу, обладающим бытием (но и многими другими качествами), но для зарождающейся модернистской философии это основание мыслилось слишком шатким и ненадежным для построения убедительной концепции Бога. Ориентация на бытие, по мнению модернистов, давала более определенные и устойчивые ориентиры в обосновании веры. На Суареса был ориентирован Декарт, а также Лейбниц, Кант, Гегель и даже Хайдеггер, считает Балтазар. Бытие как подобие или причастность превращается в концеепиию, постижимую только разумом, и тем самым принадлежащую субъекту. Для Канта и последующих философов это становится «очевидной истиной». Именно эту очевидность принадлежности бытия субъекту ставит под вопрос Хайдеггер: бытие это не субъектное бытие, а нечто гораздо более значительное. «В целом же, если предположить, что модерн начался с Декарта или одного из его современников..., мы проигнорируем важность Суареса, Скотта и Аверроэса. Хуже того, нам грозит серьезная недооценка самой эпохи модерна, неведение в отношении ее теологической составляющей», заключает Кевин Харт. Конечно, это далеко не все проблемы, поднимаемые Хартом и анализируемыми им мыслителями и постмодернистской теологией в целом, но мы надеемся, что затронули главные из них.

\section{Литература}

1 Харт К. Постмодернизм. - М.: Фаир-Пресс, 2006. - С. 163.

2 Там же.- С. 167.

3 Там же. - C. 201

4 Там же.- С. 202.

5 Там же. 